\title{
Physiological responses to low temperature
}

\author{
O. Junttila \\ Department of Plant Physiology and Microbiology, University of Tromse, Tromse, Norway
}

\section{Introduction}

Temperature is one of the main environmental factors regulating and limiting plant growth. Basic chemical and biochemical processes in plants are temperature dependent and various growth processes have their specific requirements for minimum, optimum and maximum temperatures. Distribution of woody plants is often limited by low temperature and we can separate two main effects: 1) limitation of growth and development: temperature during the growing season is too low and/or the growing season is too short for completion of growth and development, 2) limitation of survival: minimum temperatures during some period of the annual cycle are regularly lower than can be tolerated by the plant. Native species and provenances are normally adapted to local climate but responses to low temperature are of great importance when species or ecotypes are moved from their original location to new areas.

Low summer temperature has been suggested to be a limiting factor for distribution of several vascular plants in Scandinavia, primarily due to the temperature effect on oxidative phosphorylation (Skre, 1979). Generally, the temperature require- ment for generative development (flowering and seed production) is higher than that for vegetative growth. Our knowledge on exact temperature requirements for growth of various woody species is limited and very little has been done to characterize the biochemical and physiological bases for growth at low temperature.

Much more research has been devoted to studies of low temperature as a limiting factor for survival of the trees. This is partly a question of the maximum level of hardiness in the species, partly a question of a proper timing of hardening and dehardening in relation to the annual temperature variation and partly a question of tolerance of unexpected periods of low temperature. Several extensive studies (see Sakai and Larcher, 1987, for references) have clearly shown correlations between the level of cold hardiness and the local winter temperature conditions for various species. Survival adaptation to low temperature has a genetic basis, but the biochemical and physiological changes occurring in plants are regulated by an interaction of genotype and environmental factors.

The aim of this review is to give a short description of some basic aspects of environmental and genetic controls of cold 
hardiness in temperate woody plants and briefly to discuss physiological mechanisms for cold hardiness, with the main emphasis on supercooling and the role of the cell membranes.

\section{Response to frost during active growth}

Frost during the growth season is common in many areas. In Fennoscandia, frost is quite frequent during the summer and temperatures down to $-10^{\circ} \mathrm{C}$ in the middle of the growing period have been reported in southern Sweden (Christersson, 1985). In these areas, summer frost can be more injurious to forest trees than frost in winter. Generally, the frost tolerance of growing trees is very limited. There are, however, significant differences between species, but probably not between latitudinal provenances (Christersson, 1985). Seedlings of spruce are less resistant than those of pine, and birch and alder are quite hardy during active growth. Normally non-hardy tissue does not tolerate ice formation and the level of hardiness is dependent upon the degree of supercooling. This is the case with spruce and willow, while even rapidly growing shoots of pine tolerate ice formation (Christersson, 1978, 1985; Christersson et al., 1987; von Fircks, 1985).

The degree of supercooling is dependent, in addition to the rate of cooling, upon the occurrence of heterogeneous ice nuclei. It has been suggested that plants do not contain intrinsic ice nuclei active above -8 to $-11^{\circ} \mathrm{C}$ (Lindow et al., 1982), but such ice nuclei may well exist (cf. Andrews et al., 1986). In any case, certain strains of various epiphytic bacteria are important ice nucleators (ice nucleation active, (INA) bacteria). Pseudomonas syringae, one of the most effective INA bacteria, will catalyze ice formation at about $-1.5^{\circ} \mathrm{C}$. INA bacteria are known to be important for cold injury in herbaceous species (Lindow, 1983; Gusta, 1985) and this has stimulated studies on new methods to control frost injury to crops (Lindow, 1983; Hirano and Upper, 1985). One approach is to control the population density of these bacteria, another is to inhibit the nucleation activity of the bacteria. Recently, Watanabe et al. (1988) have reported a number of chemicals which inhibit the nucleation activity of INA Erwinia. Among the most effective com-

Table I. Bud set and winter damage in 2-year-old Picea seedlings grown outdoors in Troms $0,70^{\circ} \mathrm{N}$ Lat. (Junttila, unpublished).

\begin{tabular}{|c|c|c|c|c|}
\hline \multirow[t]{2}{*}{ Species } & \multicolumn{2}{|l|}{ Origin } & \multirow{2}{*}{$\begin{array}{l}\% \text { bud-set } \\
9 / 15 / 1987\end{array}$} & \multirow{2}{*}{$\begin{array}{l}\% \text { undamaged seedlings } \\
6 / 20 / 1988\end{array}$} \\
\hline & o Lat. & $m$ a.s.l. & & \\
\hline Picea $\times$ lutzii & 60 & 50 & 70 & 75 \\
\hline P. $\times$ lutzii & 61 & 70 & 86 & 92 \\
\hline P. glauca & 61 & 100 & 99 & 96 \\
\hline$P$ glauca & 63 & 530 & 100 & 100 \\
\hline P. glauca & 65 & 290 & 98 & 94 \\
\hline$P$ sitchensis & 58 & 10 & 12 & 20 \\
\hline P. sitchensis & 59 & 210 & 42 & 42 \\
\hline P. sitchensis & 60 & 10 & 8 & 8 \\
\hline P. abies & 65 & $<150$ & 72 & 92 \\
\hline P. abies & 66 & $<150$ & 78 & 78 \\
\hline P. abies & 66 & $<150$ & 44 & 80 \\
\hline
\end{tabular}


pounds was $n$-octylbenzyldimethyl-ammonium salt, which they used to protect tea plants from freeze-injury.

INA bacteria have been isolated from broadleaf species but, in a survey of 95 plant species in North America, Lindow et al. (1978) did not find INA $P$. syringae from conifers. Andrews et al. (1986) have suggested that both flower and stem tissues of peach and sweet cherry contains intrinsic ice nucleators which are active at temperatures similar to those at INA bacteria. There is an obvious need for further studies on regulation of ice formation in growing tissue of woody plants, especially in conifers.

\section{Environmental control of acclimation and deacclimation}

The main features of environmental control of cold hardiness in woody plants are now relatively well known (Weiser, 1970; Levitt, 1980). Cessation of growth is a prerequisite for normal acclimation in many woody plants. Consequently, delayed growth cessation will retard acclimation and increase the probability of frost injury. This is illustrated in Table I for some spruce species and provenances, and in Table III for various ecotypes of Salix. In most temperate zone tree species with a free growth pattern, cessation of elongation growth is primarily controlled by photoperiod (Wareing, 1956; Håbjørg, 1975). Although the critical photoperiod for cessation of growth is virtually unaffected by temperature (Heide, 1974), the rate of response to photoperiod is dependent upon temperature and, under natural conditions, the observed growth cessation is related to a joint effect of total heat sum and night length (Koski, 1985). In some cases, low temperature, drought and nutrient deficiency (especially $N$ and $P$ ) may also induce growth cessation even under long photoperiods.

The physiological basis of photoperiodic control of growth cessation is not known in detail but recent results both with herbaceous (Gilmour et al., 1986) and woody plants (Junttila and Jensen, 1988) suggest that short days block the biosynthesis of gibberellin $A_{1}$ which seems to be the effector gibberellin for shoot growth (for references, see Graebe, 1986). Short-dayinduced blockage of gibberellin biosynthesis might be the prerequisite for the cessation of apical growth, for development of dormancy and for acclimation. Studies with cell suspension cultures have shown that abscisic acid (ABA) can substitute for cold treatment and is able to induce a high level of frost hardiness (Chen and Gusta, 1983; Gusta, 1985). External applications of $A B A$ usually have a minor effect or no effect at all, on the frost hardiness of intact plants, but it is still quite probable that endogenous $A B A$ is involved in the regulation of acclimation and in the induction and maintenance of dormancy.

Normally, a combination of short days and low temperatures induces an effective

Table II. Development of cold hardiness of buds in seedlings of Salix pentandra (ecotype $70^{\circ} \mathrm{N}$ Lat.) grown in $12 \mathrm{~h}$ photoperiod at various temperature treatments.

\begin{tabular}{llll}
\hline Temperature & \multicolumn{4}{l}{$\mathrm{L} T_{50}{ }^{\circ} \mathrm{C}$ after } \\
\cline { 2 - 4 }${ }^{\circ} \mathrm{C}$ & 2 & 4 & $8 w k s$ \\
\hline 6 & -20 & -22 & -35 \\
9 & -17 & -25 & -30 \\
12 & -17 & -28 & -37 \\
15 & -16 & -25 & -38 \\
$15 / 6$ & -18 & -32 & $<-45$ \\
\hline
\end{tabular}

Seedlings were kept for two weeks at $18^{\circ} \mathrm{C}$ and $12 \mathrm{~h}$ photoperiod before they were exposed to indicated temperature treatments. $15 / 6^{\circ} \mathrm{C}$ : diurnally alternating temperature, $12 \mathrm{~h} / 12 \mathrm{~h}$. $L T_{50}$ : temperature for $50 \%$ survival. Each figure is the mean of 2 independent samples with 6-11 buds. (Junttila and Kaurin, unpublished.) 
hardening (Aronsson, 1975; Christersson, 1978; Jonsson et al., 1981). Cannel et al. (1985) have proposed a model based on day length and temperature for calculation of acclimation in P. sitchensis. Their model accurately predicted known instances of autumn frost damage at selected locations. However, at least some plants may develop a high level of hardiness without an exposure to low temperature, if they are kept for a long period under short days. This is illustrated for Salix pentandra in Table II.

Although species such as Salix may harden slowly under short days at relatively high temperature, a rapid increase in hardiness is induced by short exposures to subzero temperatures. Even one day at $-3^{\circ} \mathrm{C}$ can significantly enhance the hardiness (Junttila and Kaurin, unpublished) and this response is thought to be common for many woody species.

Deacclimation is primarily a temperature-controlled process, but both the rate and the magnitude of response to temperature treatment can greatly vary between species and cultivars. In addition, deacclimation is affected by an endogenous rhythm of the plant (Kaurin et al., 1981). In terms of the degree growth model developed by Fuchigami and his coworkers (Fuchigami et al., 1982), the rate of dehardening increases gradually when the plant changes from the stage of maximum dormancy $\left(270^{\circ} \mathrm{GS}\right)$ towards the stage of spring bud break ( $\left.360^{\circ} \mathrm{GS}\right)$. This has been shown for Pinus sylvestris in a recent study by Repo and Pelkonen (1986). We must, however, be aware that there is not necessarily any direct dependence between the physiological dormancy and the state of cold hardiness. It should also be mentioned that, in Eucalyptus, roots are involved in the dehardening process in shoots (Paton et al., 1979).

Annual changes in cold hardiness of plants are, of course, also influenced by various other conditions (availability of water, mineral nutrition, atmospheric conditions, etc.), which affect plant growth and development. Effects of various types of pollutants on the frost sensitivity of plants now need particular attention. Studies with Picea abies (Barnes and Davidson, 1988) and with $P$. sitchensis (Lucas et al., 1988) indicate that exposure of the plants to ozone increases their frost sensitivity (see also presentations at this symposium).

\section{Genetic aspects of cold hardiness}

Numerous studies with broadleaf and conifer species have shown differences in cold hardiness between various provenances and ecotypes. Normally, the maximum level of hardiness or the potential for hardening is not significantly different in various ecotypes of a tree species. For example, both a southern ( $60^{\circ} \mathrm{N}$ Lat.) and a northern $\left(70^{\circ} \mathrm{N}\right.$ Lat.) ecotypes of $S$. pentandra has the capacity to tolerate liquid $\mathrm{N}_{2}$ (Junttila and Kaurin, unpublished). However, these ecotypes differ greatly from each other in respect to the regulation of acclimation (Table III). Delayed acclimation in the southern ecotype is closely connected to delayed growth cessation. In some cases, too rapid deacclimation and/or spring bud break in relation to the local temperature conditions can be the main reason for cold injury (see Cannell et al., 1985). Thus, both the timing and the rate of acclimation/deacclimation are often more critical than the maximum level of hardiness for avoidance of frost injury in woody plants.

Results in Table III also show that both growth cessation and development of hardiness in Salix show an approximately intermediate inheritance in the $F_{1}$-generation. Photoperiodic regulation of bud set in 
Table III. Cold acclimation in various populations of Salix pentandra grown outdoors in Troms $ø, 70^{\circ}$ N Lat.

\begin{tabular}{|c|c|c|c|c|}
\hline \multirow{2}{*}{$\begin{array}{l}\text { Ecotype } \\
\text { cross }\end{array}$} & \multirow{2}{*}{$\begin{array}{l}\text { Date for } 50 \% \\
\text { growth cessation }\end{array}$} & \multicolumn{3}{|c|}{$\mathrm{LT}_{50}$ for buds, ${ }^{\circ} \mathrm{C}$} \\
\hline & & Oct. 4 & Oct. 11 & Oct. 23 \\
\hline $\begin{array}{l}70^{\circ} \\
63^{\circ} \\
60^{\circ} \\
70^{\circ} \times 60^{\circ} \text { no. } 11 \\
70^{\circ} \times 60^{\circ} \text { no. } 4\end{array}$ & $\begin{array}{l}\text { Sept. } 7 \\
\text { Sept. } 22 \\
\text { Oct. } 14 \\
\text { Sept. } 30 \\
\text { Sept. } 30\end{array}$ & $\begin{array}{l}-15.3 \\
-7.0 \\
-4.8 \\
-8.0 \\
-5.0\end{array}$ & $\begin{array}{l}<-18 \\
-15.7 \\
-11.7 \\
-14.0 \\
-14.5\end{array}$ & $\begin{array}{l}<-23 \\
-28.0 \\
-18.1 \\
-24.5 \\
-21.6\end{array}$ \\
\hline
\end{tabular}

$70^{\circ} \times 60^{\circ}: F_{1}$-generation from a cross between a northern and a southern ecotype.

Each figure is the mean of 3-5 separate samples. Results for 1986. (Junttila and Kaurin, unpublished.)

Picea has been shown to be regulated by genes with additive effects (Eriksson et al., 1978). Recently, Norell et al. (1986) have published results supporting a polygenic inheritance of frost hardiness in $P$. sylvestris. Quantitative inheritance of cold hardiness is also supported by several studies with fruit crops (Stushnoff et al., 1985).

Adaptation to climatic conditions is based on genetic mechanisms and usually takes several generations. There is, however, a possibility that significant changes can occur quite rapidly, and that we perhaps also have to be aware of longlasting physiological after-effects (Bjørnstad, 1981; Johnsen, 1988).

\section{Deep supercooling}

In the absence of heterogeneous ice nucleators, water can be undercooled until it freezes due to a homogeneous nucleation at about $-38^{\circ} \mathrm{C}$. Deep supercooling is a mechanism for avoiding freezing in the xylem of several deciduous hardwoods, in bark, in vegetative and flower buds of both hardwoods and conifers, and in seeds of various species (Burke et al., 1976; Junttila and Stushnoff, 1977; Sakai, 1978;
Quamme, 1985). Deep supercooling is dependent upon the existence of barriers for ice seeding in plant tissue. Due to such barriers, small pockets of liquid water are retained in tissue, until it is finally frozen due to a homogeneous nucleation. In tissues with deep supercooling, the killing point is normally identical or close to the freezing point of supercooled water. This freezing point can be exactly detected as a low temperature exotherm by differential thermal analysis (DTA) and the hardiness level of tissues showing deep supercooling can be rapidly measured using DTA.

Due to the temperature for homogeneous nucleation, the hardiness limit of woody plants showing deep supercooling in xylem ray parenchyma should be around $-40^{\circ} \mathrm{C}$. This has been reported to be the case with several species of deciduous hardwoods (George et al., 1974; literature cited by Quamme, 1985). However, certain species with deep supercooling are found in areas where the minimum temperature often is below $-45^{\circ} \mathrm{C}$ (Gusta et al., 1983). This study revealed that low temperature exotherms could be found as low as $-53^{\circ} \mathrm{C}$ in Quercus coccinea, Vitis riparia and Ulmus americana. In Fraxinus pennsylvanica and Prunus padus the low temperature exotherms disappeared entirely in non-thawed, fully hardy twigs (Gusta et al., 1983). Some recent studies 
also indicate that low temperature exotherms in the xylem tissue are not necessarily connected with the killing point of the tissue (L.V. Gusta, personal communication). Thus, the relationship between low temperature exotherms and tissue injury should be carefully studied before DTA is applied as a method for estimation of cold hardiness.

In the xylem, buds and seeds, the ability for supercooling is primarily dependent upon certain intact anatomical/morphological structures and, in most cases, low temperature exotherms are found both in living and dead intact tissues. In xylem, the cell walls seem to be an important barrier to ice growth, but the plasma membrane is essential for supercooling to occur at temperatures below $-40^{\circ} \mathrm{C}$ (Gusta et al., 1983). According to Quamme (1985), starch in the tissue may retain water within the cell during freezing until the point of homogeneous nucleation is reached. In floral primordia of azalea (George et al., 1974), in peach flower buds (Ashworth, 1982), and in winter buds of some conifers (Sakai, 1978), certain morphological features of the buds seem to be essential for supercooling.

\section{Membranes and frost resistance}

It is generally assumed that the cell membranes are the primary target of frost injury (Steponkus, 1984). Under natural conditions, ice in hardy tissues is normally formed extracellularly, first in areas with relatively large amounts of free water. Ice formation causes a water vapor pressure gradient and water then migrates to the ice crystals. This results in dehydration of the cells and an increase in solute concentration. For most cells, over $60 \%$ of the water is frozen at $-4^{\circ} \mathrm{C}$ and nearly all freezable water is frozen at $-15^{\circ} \mathrm{C}$ (Gusta,
1985). The availability of tissue water for freezing can, however, be an important aspect in cold tolerance. According to Vertucci et al. (1988), water in vegetative buds of a frost-sensitive apple cultivar (Golden Delicious) was more available to freeze than water in buds of a resistant cultivar (Dolgo).

Frost dehydration and rehydration during thawing induces a multitude of stresses (mechanical, chemical, thermal and possibly also electrical) (Steponkus, 1984). Often the mechanical and the chemical stresses are the most important. Hincha et al. (1987) have suggested that in vivo dehydration both by freezing and desiccation of spinach leaves results in mechanical damage, rupture of the thylakoid membrane. Cold acclimation increases the cell's ability to tolerate these stresses. Changes occurring during acclimation may decrease the extent of cell dehydration, minimize the concentration of toxic solutes and increase the stability of the cell membranes (Steponkus, 1984). Membrane stabilization may include both changes in membrane fatty acids and accumulation of cryoprotective substances. Kacperska (1985) has presented a model for frost hardening in herbaceous plants consisting of two types of mechanisms: 1) mechanisms that allow plants to function at low non-freezing temperature, (i.e., maintenance of high membrane fluidity, mainly due to a rapid increase in the content of polyunsaturated fatty acids in membrane lipids); 2) mechanisms that protect a cell against deleterious effects of frost (i.e., accumulation of compounds that increase the stability of the membranes).

The plasma membrane (plasmalemma) and the tonoplast are in many cases the primary sites of frost injury, but especially in conifers the frost resistance of the thylakoid membranes can be of great importance. Frost on cold-acclimated Scots pine can cause both reversible and irreversible 
inhibitions of photosynthesis (Strand, 1987). The reversible effect can be due to inactivation of enzymes in photosynthetic carbon reduction cycle and/or a restriction of photophosphorylation. The irreversible effect is thought to be due to an injury to the thylakoid membranes involving damage to the $\mathrm{Q}_{\mathrm{B}}$-protein (Strand, 1987; Öquist, 1987). Studies of Öquist and coworkers have also shown that a combined exposure to light and low temperature causes photoinhibition of photosynthesis in Scots pine. Photosystem II is inhibited and this effect can be observed by measuring the variable fluorescence of the $P_{\|}$. Due to the effects of temperature on the fluorescence from the $P_{\|}$, it has been suggested that measurement of chlorophyll fluorescence can be used as a screening method for frost tolerance (Sundbom et al., 1982).

\section{Future aspects}

Development of tissue and cell suspension cultures has provided new possibilities for selection and manipulation of cold hardiness. These techniques make it possible to work with an almost unlimited number of genotypes which should increase the probability of finding more hardy genotypes. In spite of the promising aspects (Chen and Gusta, 1986), so far no real success has been reported from studies of this type and probably the possibilities for successful selections from cell cultures of woody plants are rather limited. In most cases, the hardiness problem in woody plants is connected with the regulation of acclimation and deacclimation, rather than with the absolute capacity for cold hardiness. If the regulation of these processes, for example photoperiodic regulation, is dependent upon a certain stage of development and/or tissue orga- nization, then selection for these characters at the cell culture level would be difficult, if not impossible. Deep supercooling is dependent upon certain anatomical and morphological structures which are not present in cell cultures. The importance of the developmental stage for expression of cold hardiness is also shown by the fact that, although differences in frost hardiness between a hardy (Dolgo) and an unhardy (Golden Delicious) cultivar of apple could be detected in young seedlings (Stushnoff et al., 1985), there was no difference in frost hardiness of ungerminated seeds of these cultivars (Junttila and Stushnoff, unpublished). On the other hand, somaclonal variation in plants obtained from cell cultures can be a source for new, cold-hardy genotypes (Lazar et al., 1988).

A completely new line of research is emerging in connection with the development of methods for genetic transformation of plants. The process is, however, delayed by the lack of knowledge on the regulation of cold hardiness at the molecular level. Several research groups are now investigating the molecular basis of cold hardiness in higher plants. Specific proteins associated with the development of cold hardiness, either induced by low temperature or by $\mathrm{ABA}$, have been described for several herbaceous species (Robertson et al., 1988; Guy and Haskell, 1987; Gilmour et al., 1988). Such studies can lead to identification, isolation and cloning of genes which code for possible cold hardiness proteins. Small molecular organic osmolytes, such as trehalose, betaine and proline, are known to have cryoprotective effects in plant cells and genetic regulation of the biosynthesis of such compounds could provide another approach to control cold hardiness in plant cells. Genes regulating the biosynthesis of glycine, betaine and trehalose in Escherichia coli have already been identified 
(Strøm et al., 1986; Giæver et al., 1988), preparing the way for experiments with the introduction of such genes into plant cells. Development within the field of molecular biology is very rapid but, knowing the complexity of factors regulating the hardiness at the whole tree level, there is still a long way to go before we can expect major breakthroughs.

\section{Summary}

Low temperature resistance in temperate zone woody plants is characterized by a market annual variation generally showing an inverse relationship between the growth activity and the level of hardiness. These annual changes in hardiness are controlled by an interaction between the genotype and environmental factors, especially day length and temperature. Cessation of elongation growth is a prerequisite for acclimation in most species with a free growth pattern and this process is primarily controlled by photoperiod. Shortday-induced blockage of the biosynthesis of active gibberellin could be an early step leading to the cessation of growth. Cold acclimation is induced most effectively by a combination of short photoperiod and low temperature. Deacclimation is mainly a response to an increasing temperature. Cold hardiness is a quantitative character and its genetic background in woody plants is not known in any detail.

Cold hardiness during active growth is normally based on an avoidance of freezing and the level of hardiness is dependent upon the supercooling of the tissue. However, some species seem to tolerate ice formation even in a non-acclimated stage. Deep supercooling is a mechanism for cold tolerance in xylem and bud tissues of certain species, but normally the hardiness is based on the tolerance of extracellular ice formation. The cell membranes, especially the plasmalemma and the thylakoid membranes, are supposed to be the primary target of frost injury. This injury is a result of several types of stresses induced during a freeze-thaw cycle. Cold acclimation makes plant cells capable of tolerating these stresses by inducing a multitude of changes in the membranes and in their environments.

Development of methods for in vitro culture of plant cells and for genetic transformation of plants has opened up new possibilities in the study of cold hardiness. However, our knowledge of the molecular basis of cold hardiness is presently too weak to substantiate an effective use of these methods for improvement of cold hardiness in woody plants.

\section{Acknowledgments}

I would like to thank L.V. Gusta and Karen Tanino for their comments on the manuscript. Thanks are due to the Norwegian Research Council for Sciences and Humanities for financial support.

\section{References}

Andrews P.K., Proebsting E.L. Jr. \& Gross D.C. (1986) lce nucleation and supercooling in freeze-sensitive peach and sweet cherry tissues. J. Am. Soc. Hortic. Sci. 111, 232-236

Aronsson A. (1975) Influence of photo- and thermoperiod on initial stages of frost hardening and dehardening of phytotron-grown seedlings of Scots pine (Pinus silvestris L.) and Norway spruce (Picea abies (L.) Karst.). Stud. For. Suec. 128, 1-20

Ashworth E.N. (1982) Properties of peach flower buds which facilitate supercooling. Plant Physiol. 70, 1475-1479

Barnes J.D. \& Davison A.W. (1988) The influence of ozone on the winter hardiness of Norway spruce (Picea abies (L.) Karst.). New Phytol. $108,159-166$ 
Bjørnstad Å. (1981) Photoperiodical after-effect of parent plant environment in Norway spruce (Picea abies (L.) Karst.) seedlings. Rep. Norw. For. Res. Inst. 36, 1-30

Burke M.J., Gusta L.V., Quamme H.A., Weiser C.J. \& Li P.H. (1976) Freezing injury in plants. Annu. Rev. Plant Physiol. 27, 507-528

Cannell M.G.R., Murray M.B. \& Sheppard L.J. (1985) Frost avoidance by selection for late bud break in Picea sitchensis. J. Appl. Ecol. 22, 931-941

Cannel M.G.R., Sheppard L.J., Smith R.I. \& Murray M.B. (1985) Autumn frost damage on young Picea sitchensis. 2. Shoot frost hardening, and the probability of frost damage in Scotland. Forestry 58, 145-166

Chen T.H.H. \& Gusta L.V. (1983) Abscisic acidinduced freezing resistance in cultured plant cells. Plant Physiol. 73, 71-75

Chen T.H.H. \& Gusta L.V. (1986) Isolation and characterization of mutant cell lines and plants: cold tolerance. In: Cell Culture and Somatic Cell Genetics of Plants. Vol. 3. Academic Press, New York, pp. 527-535

Christersson L. (1978) The influence of photoperiod and temperature on the development of frost hardiness in seedlings of Pinus silvestris and Picea abies. Physiol. Plant. 44, 288-294

Christersson L. (1985) Frost damage during the growing season. In: Plant Production in the North. (Kaurin A, Junttila, O. \& Nilsen J., eds.), Norwegian Univ. Press, Oslo, pp. 191-198

Christersson L., von Fircks H. \& Sihe Y. (1987) Damage to conifer seedlings by summer frost and winter drought. In: Plant Cold Hardiness. (Li P.H., ed.), Alan R. Liss, Inc., New York, pp. 203-210

Eriksson G., Ekberg I., Dormling I. \& Matern B. (1978) Inheritance of bud-set and bud-flushing in Picea abies (L.) Karst. Theor. Appl. Genet. 52, 3-19

Fuchigami L.H., Weiser C.J., Kobayashi K., Timmis R. \& Gusta L.V. (1982) A degree growth stage ( ${ }^{\circ} \mathrm{GS}$ ) model and cold acclimation in temperate woody plants. In: Plant Cold Hardiness and Freezing Stress, Mechanisms and Crop Implications. (Li P.H. \& Sakai A., eds.), Academic Press, New York, pp. 93-116

George M.F., Burke M.J. \& Weiser C.J. (1974) Supercooling in overwintering azalea flower buds. Plant Physiol. 54, 29-35

Gilmour S.J., Hajela R.K. \& Thomashow M.F. (1988) Cold acclimation in Arabidopsis thaliana. Plant Physiol. 87, 745-750
Gilmour S.J., Zeevaart J.A.D., Schwenen L. \& Graebe J.E. (1986) Gibberellin metabolism in cell-free extracts from spinach leaves in relation to photoperiod. Plant Physiol. 82, 190-195

Giæver H.M., Styrvold O.B., Kaasen I. \& Strøm A.R. (1988) Biochemical and genetic characterization of osmoregulatory trehalose synthesis in Escherichia coli. J. Bacteriol. 170, 2841-2849

Græbe J.E. (1987) Gibberellin biosynthesis and control. Annu. Rev. Plant Physiol. 38, 419-465

Gusta L.V. (1985) Freezing resistance in plants. In: Plant Production in the North. (Kaurin A., Junttila O. \& Nilsen J., eds.), Norwegian Univ. Press, Oslo, pp. 219-235

Gusta L.V., Tyler N.J. \& Chen T.H.H. (1983) Deep undercooling in woody taxa growing north of the $-40^{\circ} \mathrm{C}$ isotherm. Plant Physiol. $72,122-$ 128

Guy C.L. \& Haskell D. (1987) Induction of freezing tolerance in spinach in association with the synthesis of cold acclimation induced proteins. Plant Physiol. 84, 872-878

Håbjorg A. (1978) Photoperiodic ecotypes in Scandinavian trees and shrubs. Meld. Norw. Landbrhogsk. 57, 1-20

Heide O.M. (1974) Growth and dormancy in Norway spruce ecotypes (Picea abies). I. Interaction of photoperiod and temperature. Physiol. Plant. 30, 1-12

Hincha D.K., Hefner R., Schwab K.B., Heber U. \& Schmitt J.M. (1987) Membrane rupture is a common cause of damage to chloroplast membranes in leaves injured by freezing or excessive wilting. Plant Physiol. 83, 251-253

Hirano S.S. \& Upper C.D. (1985) Ecology and physiology of $P$ seudomonas syringae. Biotechnology 3, 1073-1078

Johnsen $\emptyset$. (1988) Altered progeny performance from a southern seed orchard containing northern clones of Picea abies. I. Frost hardiness in a phytotron experiment. Scan J. For. Res. (in press)

Jonsson A., Eriksson G., Dormling I. \& Ifver J. (1981) Studies on frost hardiness of Pinus contorta seedlings grown in climate chambers. Stud. For. Suec. 157, 1-47

Junttila O. \& Jensen E. (1988) Gibberellins and photoperiodic control of shoot elongation in Salix. Physiol. Flant. 74, 371-376

Junttila O. \& Stushnoff C. (1977) Freezing avoidance by deep supercooling in hydrated lettuce seeds. Nature 269, 325-327 
Kacperska A. (1985) Biochemical and physiological aspects of frost hardening in herbaceous plants. In: Plant Production in the North. (Kaurin A., Junttila O. \& Nilsen J., eds.), Norwegian Univ. Press, Oslo, pp. 99-115

Kaurin $\AA$, Junttila O. \& Hansen J. (1981) Seasonal changes in frost hardiness in cloudberry (Rubus chamaemorus) in relation to carbohydrate content with special reference to sucrose. Physiol. Plant. 52, 310-314

Koski V. (1985) Adaptation of trees to the variation in the length of the growing season. In: Plant Production in the North. (Kaurin A, Junttila O. \& Nilsen J., eds.), Norwegian Univ. Press, Oslo, pp. 267-276

Lazar M.D., Chen T.H.H., Gusta L.V. \& Kharta K.K. (1988) Somaclonal variation for freezing tolerance in a population derived from Norstar winter wheat. Theor. Appl. Genet. 75, 480-484

Levitt J. (1980) In: Responses of Plants to Environmental Stresses. 2nd edn. Vol. I. Academic Press, New York

Lindow S.E. (1983) The role of bacterial ice nucleation in frost injury to plants. Annu. Rev. Phytopathol. 21, 363-384

Lindow S.E., Arny D.C. \& Upper C.D. (1978) Distribution of ice nucleation active bacteria on plants in nature. Appl. Environ. Microbiol. 36, 831-838

Lucas P.W., Cottam D.A., Sheppard L.J. \& Francis B.J. (1988) Growth responses and delayed winter hardening in Sitka spruce following summer exposure to ozone. New Phytol. 108, 495-504

Norell L., Eriksson G., Ekberg 1. \& Dormling I. (1986) Inheritance of autumn frost hardiness in Pinus sylvestris L. seedlings. Theor. Appl. Genet. 72, 440-448

Öquist G. (1987) Light stress at low temperature. In: Photoinhibition. (Kyle D.J., Osmond C.B. \& Arntzen C.J., eds.), 'Elsevier Science Publishers B.V., Amsterdam, pp. 67-87

Paton D.M., Slattery H.D. \& Willing R.R. (1979) Low root temperature delays dehardening of frost resistant Eucalyptus shoots. Ann. Bot. 43 , 123-124

Quamme H.A. (1985) Avoidance of freezing injury in woody plants by deep supercooling. Acta Hortic. 168, 11-27

Repo T. \& Pelkonen P. (1986) Temperature step response of dehardening in Scots pine seedlings. Scan. J. For. Res. 1, 271-284
Robertson A.J., Gusta L.V., Reaney M.J. \& Ishikawa M. (1988) Identification of proteins correlated with increased freezing tolerance in bromegrass (Bromus inermis Leyss. Cv. Manchar) cell cultures. Plant Physiol. 86, 344-347

Sakai A. (1978) Low temperature exotherms of winter buds of hardy conifers. Plant Cell Physiol. 19, 1439-1446

Sakai A. \& Larcher W. (1987) Frost survival of plants. In: Ecological Studies, Vol. 62, Springer Verlag, Berlin, pp. 340

Skre O. (1979) The regional distribution of vascular plants in Scandinavia with requirements for high summer temperatures. Norw. J. Bot. 26, 295-318

Steponkus P.L. (1984) Role of plasma membrane in freezing injury and cold acclimation. Annu. Rev. Plant Physiol. 35, 543-584

Strand M. (1987) Photosynthetic responses of seedlings of Scots pine (Pinus sylvestris L.) to low temperature and excessive light. Ph.D. Thesis. Univ. of Umeå, Umeå. ISBN 91-7174308-1

Strom A.R., Falkenberg P. \& Landfald B. (1986) Genetics of osmoregulation in Escherichia coli: uptake and biosynthesis of organic osmolytes. FEMS Microbiol. Rev. 39, 79-86

Stushnoff C., Junttila O. \& Kaurin $\AA$ (1985) Genetics and breeding for cold hardiness in woody plants. In: Plant Production in the North. (Kaurin A., Junttila O. \& Nilsen J., eds.), Norwegian Univ. Press, Oslo, pp. 141-156

Sundbom E., Strand M. \& Hällgren J.E. (1982) Temperature-induced fluorescence changes. A screening method for frost tolerance of potato (Solanum sp.). Plant Physiol. 70, 1299-1302

Vertucci C.W., Stushnoff C. \& Towill L.E. (1988) The loss of "vital" water contributes to differences in apple bud hardiness. Plant Physiol. Suppl. 86, 38

von Fircks H.A. (1985) Frost hardiness of fastgrowing Salix species. In: Plant Production in the North. (Kaurin A, Junttila O. \& Nilsen J., eds.), Norwegian Univ. Press, Oslo, pp. 199204

Weiser C.J. (1970) Cold resistance and injury in woody plants. Science 169, 1269-1278

Wareing P.F. (1956) Photoperiodism in woody plants. Annu. Rev. Plant Physiol. 7, 191-214

Watanabe M., Makino T., Okada K., Hara M., Watabe S. \& Arai S. (1988) Alkylbenzyldimethyl-ammonium salts as inhibitors for the ice nucleating activity of Erwinia ananas. Agric. Biol. Chem. 52, 201-206 